\title{
Influence of annealing conditions on the properties and microstructure of steel composites
}

\author{
Wpływ warunków wyżarzania \\ na właściwości i mikrostrukturę kompozytów \\ o osnowie stali austenitycznej
}

\begin{abstract}
Samples made of AISI 316 L stainless steel reinforced with 8 vol.\% TiB2 particles were prepared using the high pressure-high temperature (HP-HT) method. Next, the composites were annealed at a temperature of $1200^{\circ} \mathrm{C}$ for different holding times. The influence of the annealing temperature and time on the properties and microstructure of AISI316L $+8 \%$ vol.TiB2 composites was investigated. The structural studies showed the formation of phases containing chromium, molybdenum and boron.
\end{abstract}

Key words: composites, annealing, properties, diboride titanium

\section{Streszczenie}

Głównym celem pracy było określenie wpływu temperatury oraz czasu wyżarzania na właściwości i mikrostrukturę kompozytów umacnianych ceramiką TiB2. Proces spiekania materiałów kompozytowych o osnowie stali austenitycznej przeprowadzono przy zastosowaniu spiekania wysokociśnieniowego-wysokotemperaturowego (HP-HT). Kompozyty były wyżarzane w temperaturze $1200^{\circ} \mathrm{C}$ w różnych czasach. Stwierdzono, że mikrotwardość oraz odporność na ścieranie obniża się już po 30 minutach wyżarzania. Badania mikrostrukturalne wykazały powstanie dużych faz zawierających chrom, molibden oraz bor.

Słowa kluczowe: kompozyty, wyżarzanie, właściwości, dwuborek tytanu

Iwona Sulima Ph.D. Eng., Paweł Hyjek Ph.D. Eng.: Institute of Technology, Pedagogical University in Cracow; Tomasz Tokarski Ph.D. Eng.: AGH University of Science and Technology, Faculty of Non-Ferrous Metals, Krakow, Poland; isulima@up.krakow.pl 


\section{Introduction}

Metal matrix composites (MMCs) are currently being developed as possible structural materials, offering improved elastic modulus, strength, good properties elevated temperature and control over the coefficient of thermal expansion [1,2]. The addition of high modulus refractory particles to a ductile metal matrix produces a material which properties are intermediate between the matrix alloy and ceramic reinforcement. However, the optimum properties of metal matrix composites depends additionally on a proper selection of the metallic matrix material, the reinforcing phase, the methods of producing and the parameters of these methods $[3,4]$.

The $316 \mathrm{~L}$ austenitic stainless steel is nowadays a widely used engineering material due to its excellent corrosion and oxidation resistance and good formability. However, the application of this material is hindered by its low mechanical strength and poor anti-friction properties. Strengthening stainless steel has drawn much attention in the past decades and various approaches have been developed, such as varying its chemical compositions to induce solid solution hardening and grain refinement [5-8]. Nowadays, the $\mathrm{TiC}$ and $\mathrm{TiB}_{2}$ particles are expected to be the best reinforcements for steel matrix composites because of their high thermal stability at a higher temperature, good wettability, high modulus of elasticity, low density and their relative stability with steel matrix [9]. The experiments of the authors [10-14] have shown that steel matrix composites reinforced with $\mathrm{TiB}_{2}$ particulates have increased mechanical strength, hardness, and wear resistance. In future, such materials may find their application in the manufacturing of products and semi-products operating in changing operating conditions. In this case, the determination of the influence of temperature and the duration of heat-treatment on the properties and structure of composites is an important issue due to their further application and utilization.

In the present study, steel matrix composites reinforced with submicron-scale $\mathrm{TiB}_{2}$ particles were fabricated by the high pressure-high temperature sintering method. The effects of annealing conditions on the microstructures and properties of composites were investigated.

\section{Experimental procedure}

Powders of $99.9 \%$ pure titanium diboride (H.C. Starck) and austenitic stainless steel with an average particle size of 2.5-3.5 $\mu \mathrm{m}$, respectively, were used in this work. The composite powders were prepared by mixing in a turbula mixer for 12 hours. The composites were consolidated using the high pressure-high temperature (HP-HT) method. Figure 1 presents the scheme of the Bridgman-type HP-HT apparatus. The mixtures were preliminarily consolidated into pellets of diameter $15 \mathrm{~mm}$ and height $5 \mathrm{~mm}$ under pressure of $\sim 200 \mathrm{MPa}$. Next, the discs were placed into the internal graphite heater in a special gasket assembly for sintering (Fig. 2). The samples were sintered at temperatures of $1000^{\circ} \mathrm{C}$ and $1300^{\circ} \mathrm{C}$ and a pressure of $7 \pm 0.2 \mathrm{GPa}$ for 60 seconds. 


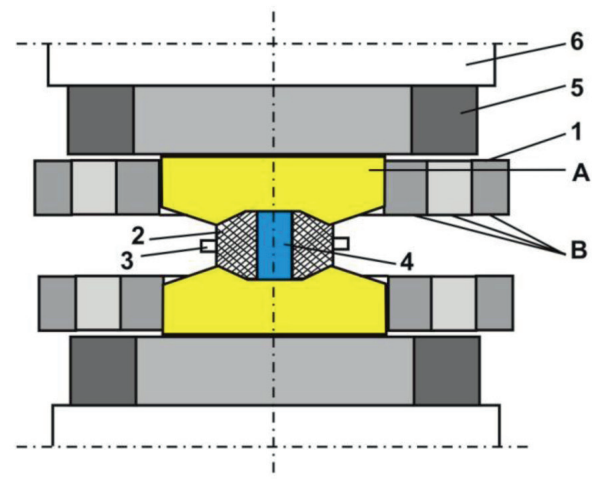

Fig. 1. Cross-section of the high pressure - high temperature Bridgman type apparatus: 1 - cell pressure (A-carbideanvil, $B$-setofsteelrings);2-pyrophyllitegasket;3-pyrophyllitering;4-assemblyforsintering; 5 - carbide backing block; 6 - bottom platen [15]

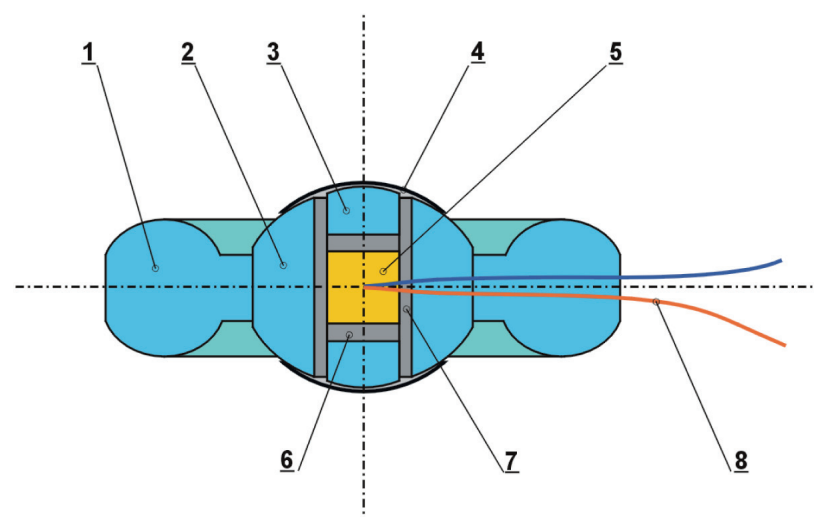

Fig. 2. Assembly for high pressure-high temperature sintering:1 - pyrophyllite external gasket; 2 - internal gasket; 3 - ceramic plate; 4 - molybdenium plate; 5 - sintered sample; 6, 7 -graphite heate; 8 - thermocouple (optionally) [16]

Main advantages of the HP-HT method are:

- shortening of the duration of the sintering,

- possibility of application of the sintering temperature of $2000^{\circ} \mathrm{C}$ and higher depending on the duration of the sintering,

- acceleration of diffusion process almost $100 \%$ degree of consolidation of sinters,

- very low porosity,

- prohibits the grain growth of materials,

- refined microstructure of sintered materials,

- possibility of sintering of a large group of materials, for example: diamond cubic boron nitride $(\mathrm{CBN}), \mathrm{TiB}_{2}$ ceramics, gradient materials, composite materials and others. 
The densities of the sintered samples were determined by weighing in air and water using the Archimedes' method. Uncertainty of measurements was $0.02 \mathrm{~g} / \mathrm{cm}^{3}$. Young's moduli of the composites were measured based on the velocity of the ultrasonic waves transition through the sample using ultrasonic flaw detector Panametrics Epoch III. The accuracy of calculated Young's modulus is estimated at 2\%. Next, samples were polished using conventional polishing techniques. Sintered samples were prepared by lapping on a cast iron plate with diamond paste. The microhardness of the composites was tested by means of a Vickers microhardness tester (NEXUS 4000), the applied load was of $2.94 \mathrm{~N}$. Standard deviations of HV0.3 values were no more than $4 \%$ of the average values.

After sintering the composites were annealed at $1200^{\circ} \mathrm{C}$ in a furnace for different holding times such as $0.5,1,2,4,8,16$ and $32 \mathrm{~h}$. Annealing was carried out in a vacuum of about $10^{-4} \mathrm{MPa}$. Each sample was placed separately in a quartz tube where a vacuum was attained, next the tube was closed and put in the furnace. The heat rate was $5^{\circ} \mathrm{C} / \mathrm{min}$. After each annealing stage, the metallographic specimen was prepared. Then, microhardness was measured and the structure of the composites was observed. A JEOL JSM $6610 \mathrm{LV}$ scanning electron microscope with energy dispersive spectrometry (EDS) and $\mathrm{Hi}$ tachi SU-70 with Wavelenght Dispersive Spectroscopy (WDS) were used for microscopy studies of composites before and after the annealing treatment.

The tribological properties for composites were examined before and after annealing ( $32 \mathrm{~h}$ ). Tribological tests were carried out at UMT-2T (producer CETR, USA) ball-on-disk tribotester. The tests were carried out without lubricant according to the ISO 20808:2004(E) standard [17]. For the ball-on-disk method the sliding contact is brought by pushing a ball on a rotating disc specimen under a constant load. The loading mechanism applies a controlled load $F_{n}$ to the ball holder. The friction force was measured continuously during the test using the extensometer. For each test, a new ball was used or the ball was rotated such that a new surface was in contact with the disc. After the mounting of the ball and sample, materials were washed in ethyl alcohol and dried. The roughness of the test surface was not more than $0.1 \mu \mathrm{m} \mathrm{R}_{\mathrm{a}}$. The following test conditions were established: ball made of $\mathrm{Al}_{2} \mathrm{O}_{3}$ (diameter of $3.175 \mathrm{~mm}$ ), friction track diameter $4 \mathrm{~mm}$, applied load $4 \mathrm{~N}$; sliding speed $0.1 \mathrm{~m} / \mathrm{s}$; total sliding distance: $200 \mathrm{~m}$, test duration: 2000s; room temperature. The friction coefficient and specific wear rate were determined.

\section{Results}

The selected physical-mechanical properties of composites sintered at different temperatures are presented in Table 1 . The composites with the addition of $8 \% \mathrm{vol}$. $\mathrm{TiB}_{2}$ were characterized by a high degree of densification: $98 \%$ and $100 \%$ of the theoretical density. Also, it showed no significant effect of sintering temperature on the Young's modulus. The values of Young's modulus are a similar: of $217 \mathrm{GPa}$ and $221 \mathrm{GPa}$ for 
a temperature of $1000^{\circ} \mathrm{C}$ and $1300^{\circ} \mathrm{C}$, respectively. However, the microhardness deceases with increasing the sintering temperature. In case of the temperature of

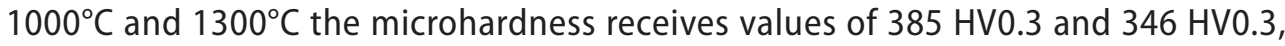
respectively.

Table 1. The properties of composites with $8 \%$ vol. TiB2 before annealing at $1200^{\circ} \mathrm{C}$

\begin{tabular}{|c|c|c|c|}
\hline Composites & Sin & eters & \\
\hline \multirow{9}{*}{ 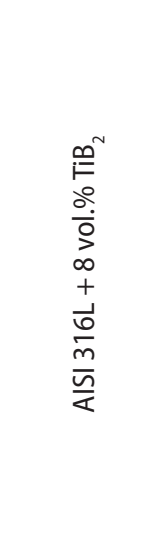 } & Temperature, $\left[{ }^{\circ} \mathrm{C}\right]$ & 1000 & 1300 \\
\hline & Pressure, [GPa] & \multicolumn{2}{|c|}{7} \\
\hline & \multicolumn{3}{|c|}{ Examined properties } \\
\hline & Relative density $\left(\rho_{0}\right),\left[\mathrm{g} / \mathrm{cm}^{3}\right]$ & 7,73 & 7,81 \\
\hline & $\frac{\rho_{0}}{\rho_{\text {Teor }}}$ & 98 & 100 \\
\hline & Poisson's ratio & 0.3 & 0.3 \\
\hline & Young's modulus, [GPa] & 217 & 221 \\
\hline & $\frac{E}{E_{0}}[\%]$ & 92 & 93 \\
\hline & Vickers microhardness, HV0.3 & 385 & 346 \\
\hline
\end{tabular}

The composite materials were annealed at $1200^{\circ} \mathrm{C}$ in subsequent times $0.5,1,2,4$, 8,16 and $32 \mathrm{~h}$. After each stage of the annealing, the metallographic specimens were prepared and microhardness was determined. Besides, observations of microstructure in time of the annealing were made. The results of microhardness measurements of the composites in the function of time are presented in Figure 3 . Only after $0.5 \mathrm{~h}$ of the annealing of the composite materials, the drop of microhardness by $40 \%$ is noted. In the case of the composite sintered at $1000^{\circ} \mathrm{C}$, the microhardness decreased from $385 \mathrm{HV} 0.3$ to $244 \mathrm{HVO} 0.3$ but in the case of the composite sintered at $1300^{\circ} \mathrm{C}$ it decreased from $346 \mathrm{HV} 0.3$ to $185 \mathrm{HV} 0.3$. Prolongation of time of subsequent annealing cycles did not influence significantly the change of microhardness of the studied materials. After $32 \mathrm{~h}$ of annealing, the composites sintered at $1000^{\circ} \mathrm{C}$ and $1300^{\circ} \mathrm{C}$ achieved a similar microhardness of 215 HV0.3 and 207 HV0.3, respectively.

The drop in microhardness of the studied materials is connected with the microstructure changes appearing during annealing at $1200^{\circ} \mathrm{C}$. The selected microstructure images of the composite materials taken before and after the annealing process are presented for comparison in Figures 4 and 5. Figures $4 a$ and $5 a$ correspond to the sintered composites before annealing. The $\mathrm{TiB}_{2}$ particles (dark particles) are distributed nearly homogeneously in the steel matrix. Such a kind of particulate distribution is an important requirement to achieve enhanced mechanical and tribological properties of the composites. 


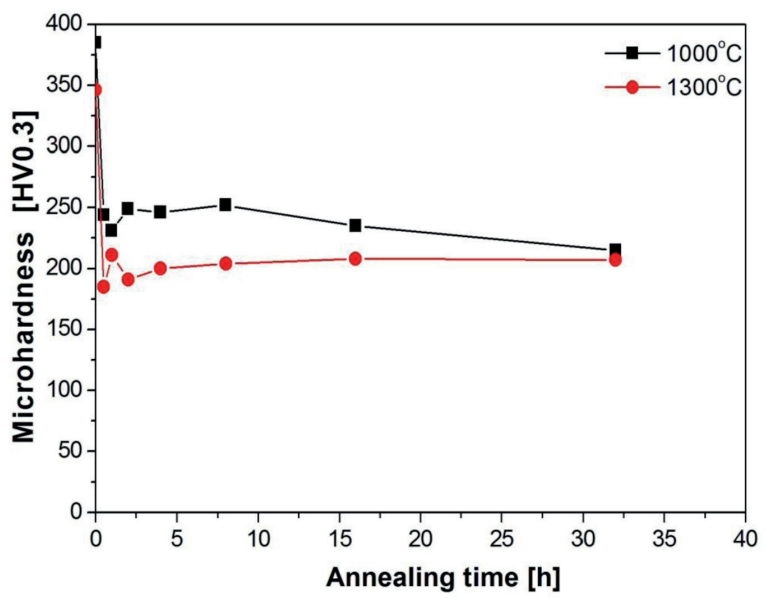

Fig. 3. Variation of microhardness with time of annealing

a)

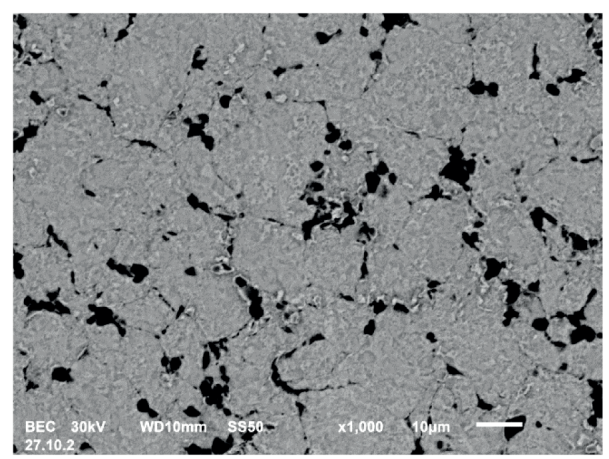

b)

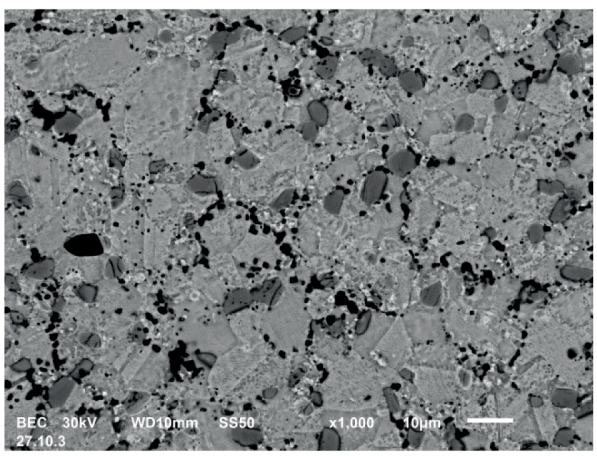

Fig. 4. The microstructure of composites sintered at $1000^{\circ} \mathrm{C}$ : a) before annealing; b) after annealing at $1200^{\circ} \mathrm{C}$ for $32 \mathrm{~h}$

c)

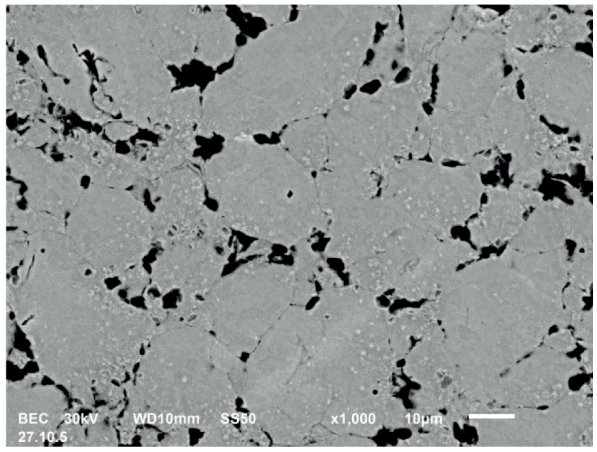

d)

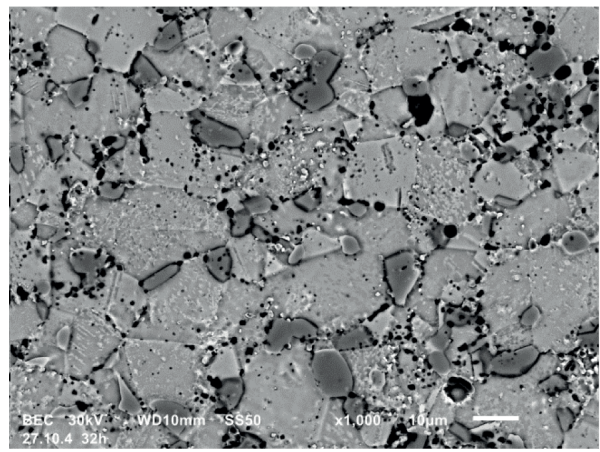

Fig. 5. The microstructure of composites (sintering temperature of $1300^{\circ} \mathrm{C}$ ): a) before annealing; b) after annealing at $1200^{\circ} \mathrm{C}$ for $32 \mathrm{~h}$ 
On the contrary, Figures $4 \mathrm{~b}$ and $5 \mathrm{~b}$ present the microstructure of the composite after $32 \mathrm{~h}$ of annealing at $1200^{\circ} \mathrm{C}$. A change of morphology of $\mathrm{TiB}_{2}$ precipitates (their refinement, coagulation and change of shape) was observed. The microstructure analysis indicated distribution of fine oval $\mathrm{TiB}_{2}$ precipitates along the steel grain boundaries. Additionally, new large precipitates (medium-gray) with irregular shape appeared in the microstructure. It is to underline, that the observed changes in the microstructure manifested themselves only after $0.5 \mathrm{~h}$ of heat-treatment (Fig. 6). After the first stage of the treatment, new precipitates containing chromium, molybdenum and boron (results of point analysis by EDS are shown in Figure 6 and Table 2) form. The microstructure observations after successive cycles of treatment indicate an increase in the amount and size of the precipitates and change of the morphology of $\mathrm{TiB}_{2}$ particles in a composite matrix. Moreover, WDS analysis (Fig. 7) confirmed the presence of chromium, molybdenum and boron in the observed precipitates. It can be suspected that during annealing, boron diffuses from ceramic $\mathrm{TiB}_{2}$ into steel matrix followed by reaction with chromium and molybdenum, and finally forming a non-stoichiometric boride compound. The WDS analysis (Fig. 8) of the composite before annealing indicates the presence of $\mathrm{TiB}_{2}$ precipitates only. In the case of these materials, the formation of regions rich in nickel next to $\mathrm{TiB}_{2}$ precipitates was observed. The next stage of research will be a detailed microstructure analysis aimed at the identification of the formed precipitates.

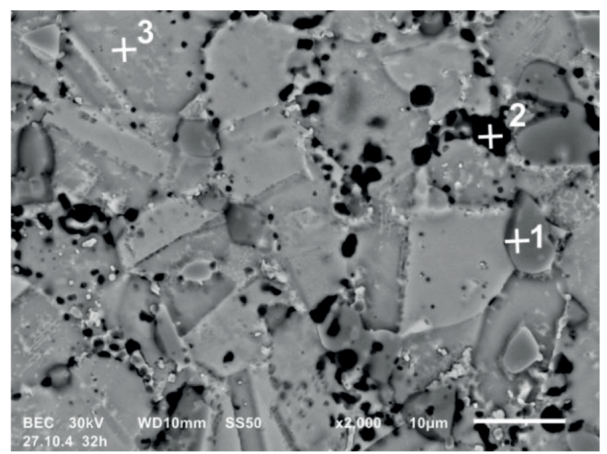

Fig. 6. The microstructure of composites (sintered at $1300^{\circ} \mathrm{C}$ ) after annealing $0.5 \mathrm{~h}$ and corresponding point analysis (EDS)

Table 2. Point analysis of the analyzed composites

\begin{tabular}{|c|c|c|c|c|c|c|c|c|}
\hline \multirow{2}{*}{$\begin{array}{c}\text { Point } \\
\text { analysis }\end{array}$} & \multicolumn{8}{|c|}{ Chemical composition, [\% wt.] } \\
\cline { 2 - 9 } & $\mathbf{F e}$ & $\mathbf{C r}$ & $\mathbf{N i}$ & $\mathbf{T i}$ & $\mathbf{B}$ & $\mathbf{M o}$ & $\mathbf{M n}$ & $\mathbf{S i}$ \\
\hline 1 & 41.8 & 50.2 & 2.2 & 0.7 & 0.0 & 3.4 & 0.3 & 0.2 \\
\hline 2 & 24.9 & 8.2 & 5.0 & 45.3 & 15.4 & 0.7 & 0.1 & 0.4 \\
\hline 3 & 56.4 & 17.9 & 12.7 & 1.8 & 0.0 & 1.2 & 0.2 & 0.8 \\
\hline
\end{tabular}



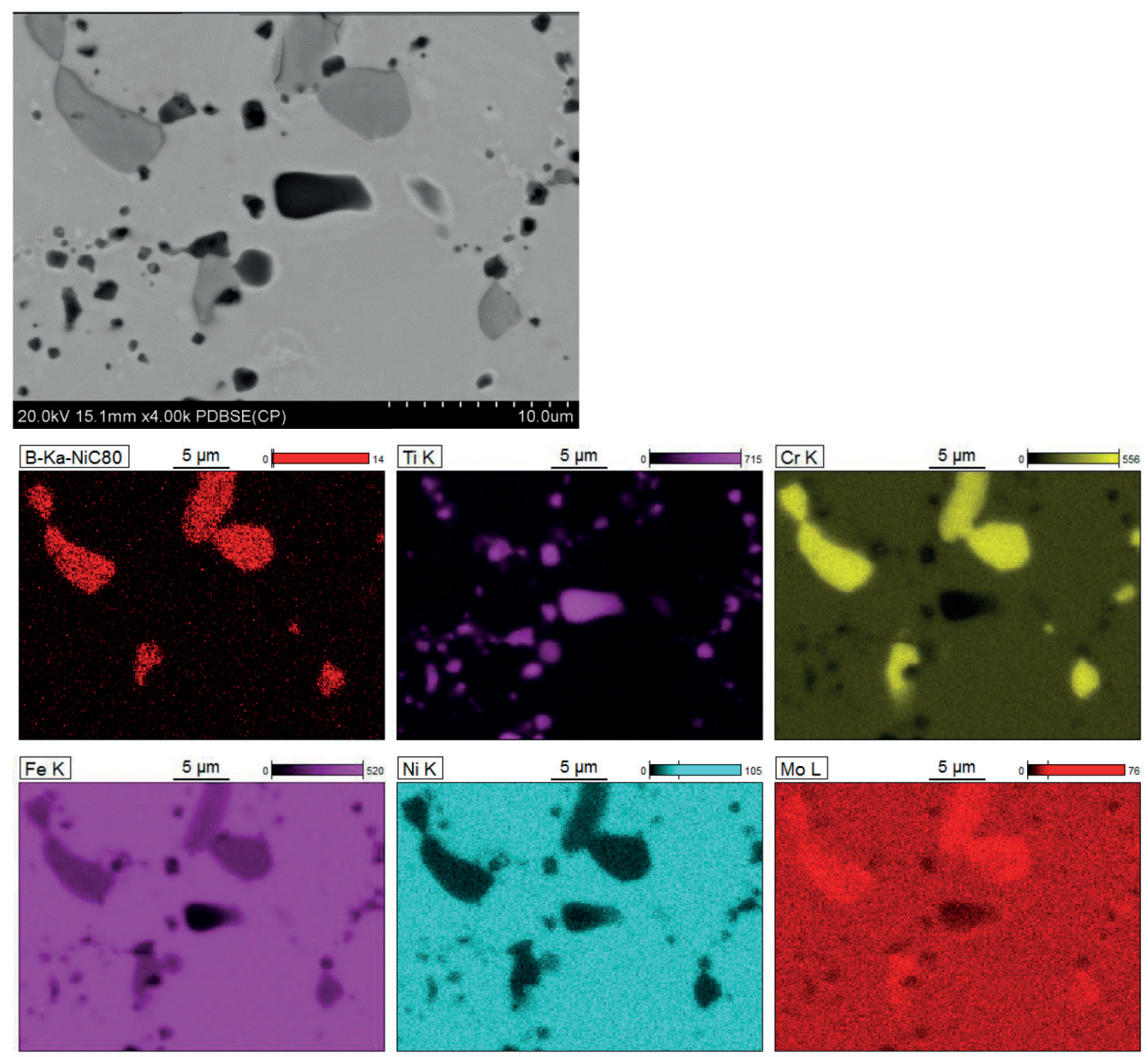

Fig. 7. The microstructure of composites (sintered at $1300^{\circ} \mathrm{C}$ ) after annealing at $1200^{\circ} \mathrm{C}$ for $32 \mathrm{~h}$ with area analysis WDS

Next, the effectof the annealing conditions on the tribological properties of composites with $8 \%$ vol. $\mathrm{TiB}_{2}$ were investigated. The wear rates and the friction coefficient obtained by ball-on-disk experiments are presented in Figure 9. Many hours of annealing also affected negatively the tribological properties of the composites: the friction coefficients are higher for the annealed composites (0.7-0.75) as compared to the values of the friction coefficient (0.5-0.56) of composites before the annealing (Fig. 9a). The specific wear rate is significantly higher for composites which were annealed at $1200^{\circ} \mathrm{C}$. In this case, the wear rates oscillate $(648-715) \cdot 10^{-6} \mathrm{~mm}^{3} / \mathrm{Nm}$. It is evident that the applied heat treatment influences negatively wear resistance of materials. This is the result of the lower hardness and the fast wear of the steel composites. 

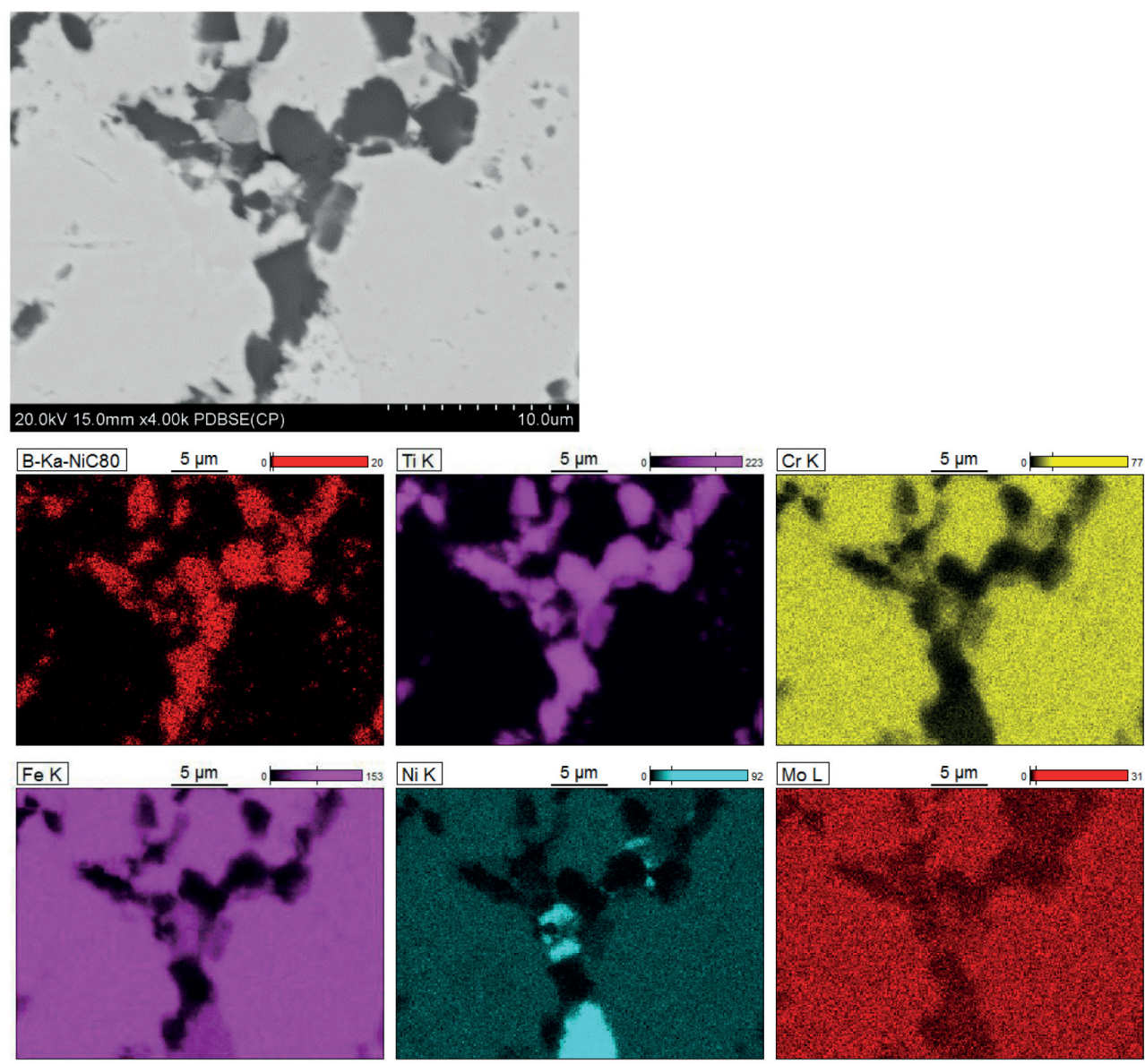

Fig. 8. The microstructure of composites (sintered at $1300^{\circ} \mathrm{C}$ ) before annealing with area analysis WDS

a)

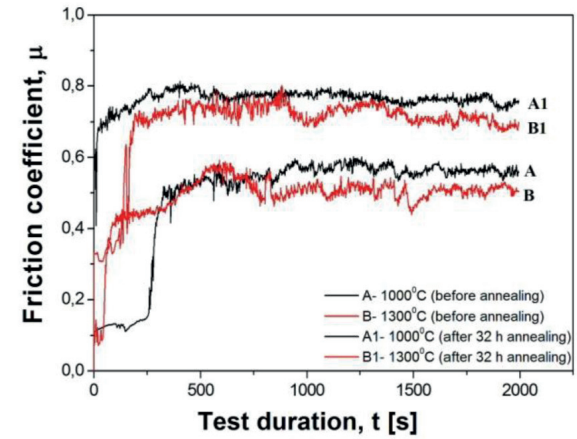

b)

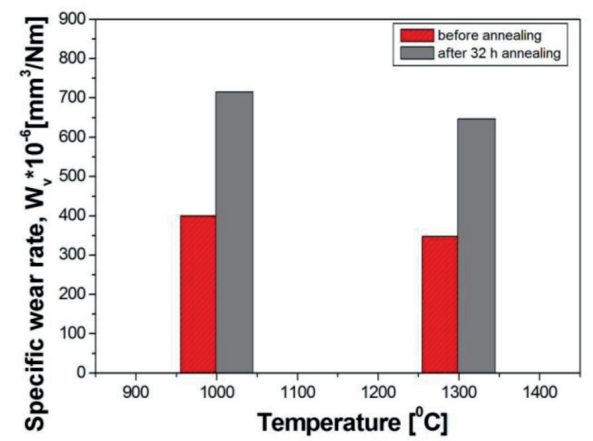

Fig. 9. The results of the: a) friction coefficient as a function of test duration; $b$ ) specific wear rate as a function of temperature 


\section{Conclusions}

Two variants of the steel- $\mathrm{TiB}_{2}$ composites with 8 vol. $\%$ of $\mathrm{TiB}_{2}$ particles were investigated. The results showed that applied annealing conditions influenced negatively the steelmatrix composites. Evidently, the microhardness and wear resistance of the composites decreased when applied first annealing step ( $0.5 \mathrm{~h}$ ). Prolonged time to $32 \mathrm{~h}$ did not affect significantly the tested properties due to the change of microstructure of the composites and the formation of phases containing chromium, molybdenum and boron.

\section{Acknowledgements}

This work was carried out with financial support through statutory funds of Pedagogical University in Cracow.

\section{References}

[1] He P., Yue X., Zhang J.: Hot pressing diffusion bonding of a titanium alloy to a stainless steel with an aluminum alloy interlayer. Materials Science and Engeenering A, 486 (2008), 171-176

[2] Emadoddin E., Tajally M., Masoumi M.: Damping behavior of Al/SiCP multilayer composite manufactured by roll bonding. Materials \& Design, 42 (2012), 334-338

[3] Mazahery A., Shabani M.O.: Tribological behaviour of semisolid-semisolid compocast Al-Si matrix composites reinforced with TiB2 coated B4C particulate. Ceramics International, 38 (2012), 1887-1889

[4] Nagarajan S., Dutta B.: The effect of SiC particles on the size and morphology of eutectic silicon in cast A356/SiC composites. Composites Science and Technology, 59 (1999), 897-902

[5] Pelletier H., Muller D., Mille P., Cornet A., Grob J.J.: Dose effect on mechanical properties of high-energy nitrogen implanted 316L stainless steel. Surface and Coating Technology, 151 (2002), 377-385

[6] Rawers J., Crogdon F., Krabbe R., Duttlinger N.: Tensile characteristics of nitrogen enhanced powder injection moulded 316 Ltainless steel. Powder Metallurgy, 39 (1996), 125-129

[7] Ucok I., Ando T., Grant N.J.: Property enhancement in Type 316L stainless steel by spray forming. Materials Science and Engeenering, 133A (1991), 284-287

[8] Chen X.H., Lu J., Lu L., Lu K.: Tensile properties of a nanocrystalline $316 \mathrm{~L}$ austenitic stainless steel. Scripta Materialia, 52 (2005), 1039-1044

[9] Farid A., Guo S., Feng F.C.P., Lin T.: TiB ${ }_{2}$ and TiC stainless steel matrix composites. Materials Letters, 61 (2007), 189-191

[10] Tjong S.C., Lau K.C.: Abrasion resistance of stainless-steel composites reinforced with hard TiB ${ }_{2}$ particles. Composites Science and Technology, 60 (2000), 1141-1146

[11] Bacon D.H., Edwards L., Moffatt J.E., Fitzpatrick M.E.: Fatigue and fracture of a 316 stainless steel metal matrix composite reinforced with 25\% titanium diboride. International Journal of Fatigue, 48 (2013), 39-47

[12] Wang Y., Zhang Z.Q., Wang H.Y., Ma B.X., Jiang Q.C.: Effect of Fe content in Fe-Ti-B system on fabricating $\mathrm{Ti}_{2}$ particulate locally reinforced steel matrix composites. Materials Science and Engineering, $422 \mathrm{~A}$ (2006), 334-39

[13] Sulima I., Klimczyk P., Malczewski P.: Effect of TiB ${ }_{2}$ particles on the tribological properties of stainless steel matrix composites. Acta Metallurgica Sinica (English Letter), 27, 1 (2014), 12-18 
[14] Sulima I., Jaworska L., Figiel P.: Influence of processing parameters and different content of TiB ${ }_{2}$ ceramics on the properties of composites sintered by high temperature - high pressure (HT-HP) method. Archives of Metallurgy and Materials, 59, 1, (2014), DOI: 10.2478/amm-2014-0033

[15] Jaworska L.: Ceramic cutting-edge materials, Tooling Materials, The Institute of Advanced Manufacturing technology, Krakow, 2011

[16] Jaworska L.: Wysokociśnieniowe spiekanie proszków diamentowych. Prace IOS, seria Zeszyty Naukowe, 82, Kraków, 2002

[17] International Standard, Fine ceramics (advanced ceramics, advanced technical ceramics) - Determination of friction and wear characteristics of monolithic ceramics by ball-on-disc method, ISO 20808:2004(E) 